\title{
MÚLT-JELEN-JÖVŐ a hazai mezőgazdasági talajvizsgálatokban
}

\author{
${ }^{1}$ VonA Viktória, ${ }^{1}$ BAKOs István Attila, ${ }^{1}$ GICZI Zsolt, ${ }^{1}$ KALOCSAI Renátó, \\ ${ }^{2}$ VonA Márton, ${ }^{3}$ KuLMÁNY István Mihály, ${ }^{4 *}$ CENTERI Csaba \\ ${ }^{1}$ Széchenyi István Egyetem, Mezőgazdasági- és Élelmiszertudományi Kar, Víz- és \\ Környezettudományi Tanszék, Mosonmagyaróvár; ${ }^{2}$ Csernozjom Kft., Nagykörü; \\ ${ }^{3}$ Nemzeti Agrárkutatási és Innovációs Központ, Agrárgazdasági Kutatóintézet, \\ Budapest; ${ }^{4}$ Szent István Egyetem, Természetvédelmi és Tájgazdálkodási Tanszék, \\ Gödöllö
}

Erratum: Agrokémia és Talajtan 69 (1-2) (2020) 127-151

DOI: $10.1556 / 0088.2020 .00061$

A közlemény angol nyelvü összefoglalója hibásan jelent meg. In the original review the English summary was incorrect.

\section{PAST-PRESENT-FUTURE in Hungarian soil analyses}

\author{
${ }^{1}$ Viktória VonA, ${ }^{1}$ István Attila BAKOs, ${ }^{1}$ Zsolt GicZI, ${ }^{1}$ Renátó KALOCSAI, ${ }^{2}$ Márton VonA, \\ ${ }^{3}$ István Mihály KULMÁNY, ${ }^{4 *}$ Csaba CENTERI \\ ${ }^{1}$ Department of Hydrology and Environmental Sciences, Faculty of Agricultural and \\ Food Sciences, Széchenyi István University, Mosonmagyaróvár; ${ }^{2}$ Csernozjom Kft., \\ Nagykörü; ${ }^{3}$ Research Institute of Agricultural Economics, National Agricultural \\ Research and Innovation Centre, Budapest; ${ }^{4}$ Department of Nature Conservation and \\ Landscape Management, Faculty of Agricultural and Environmental Sciences, Szent \\ István University,Gödöllő
}

\begin{abstract}
Summary
Authors aim was to deliver a compilation of Hungarian soil analysis methods as well as to present the advisory system for nutrient management. Both are based on several decades of work. We should learn from these past experiences of reasonable and good agricultural practices. We can only apply the present and future results of soil science and find out what direction should we develop if we were aware of the results of the past and we calculate with their governing effects. The majority of our recent methods are based on historical researches and the current state of our scientific field can only be judged and developed if we knew the former history of the methodological findings. The recent Hungarian soil analysis system provides useful results; however, the adaptation of new international methods might open new perspectives for the Hungarian laboratory analyses methodology. The never-met demand for cost and time effective, environmentally friendly soil analysis methods underpin how actual and hot the topic is.
\end{abstract}

